\title{
FISCAL AND MACROECONOMIC POLICIES DYNAMICS IN NIGERIA
}

\author{
OGAR, A., ARIKPO, O. F. AND SULEIMAN, L. G.
}

(Received 18 February 2019; Revision Accepted 5 April 2019)

\begin{abstract}
This study examined fiscal policy and macroeconomic policy dynamics in Nigeria. The study specifically assessed whether there is a long run and short run causal relationship running from fiscal policy instruments such as government revenue, government expenditure and debt to macroeconomic variables such as interest rate and GDP in Nigeria. The data for the study were source from the CBN statistical bulletin for the period 1980 to 2016. The exploratory design was combined with the ex-post facto research design; the data collection method was desk survey. The study used the Vector Error Correction Mechanism (VECM) for data analysis. Findings from the analyses showed that there is no long run and short run causality running from fiscal policy instruments such as government revenue, government expenditure and debt to interest rate in Nigeria. The study also showed that there is no long run and short run causality running from fiscal policy instruments such as government revenue, government expenditure and debt to GDP in Nigeria. The study on the basis of these findings recommends that Fiscal policy should be tailored towards sustaining economic growth and development; in view of this government avoid further borrowings as this may increase the debt servicing burden and result in a negativity effect on growth in the long run and lastly that fiscal policy should be used to complement monetary policy effects as if used alone may not achieve the desired target for interest rate in Nigeria.
\end{abstract}

KEYWORDS: Government Expenditure, Government Revenue, Government Debt, Fiscal Policy, Interest rate, Inflation rate, Economic growth.

\section{INTRODUCTION}

The need to achieve improved balance of payments position, balance industrial development, high employment level, increased productivity, equitable income distribution, high revenue sources, price stability and economic growth has necessitated the development of various macroeconomic policies. Macroeconomic policies suggest the combination of government fiscal and monetary policies. It incorporates all policy frameworks geared at achieving a sound, stable and vibrant economy.
Fiscal policy as a tool for macroeconomic management has been defined as a purposeful use of government revenue (majorly from taxes) and expenditure to manipulate the level of economic activities in a country (Akpapan, 1994). It can also be conceived as part of government policy relating to the raising of revenue through taxation and other means and choosing on the level and pattern of expenditure for the purpose of manipulating economic activities or achieving some needed macroeconomic goals (Anyanwu and Ohahenam, 1995).

The implementation of fiscal policy is essentially

Ogar, A., Department of Banking and Finance, University of Calabar, Calabar Nigeria.

Arikpo, O. F., Department of Banking and Finance, University of Calabar, Calabar Nigeria.

Suleiman, L. G., Department of Banking and Finance, University of Calabar, Calabar Nigeria. 
routed through government's budget. Budget as a fiscal policy tool could be conceived as a structure that balances the changes in government revenue against expenditure over a period of time. It is a comprehensive financial plan, setting forth the expected route for achieving the financial and operational goals of a country (Meigs and Meigs, 2004).

The intent of fiscal policy is to stimulate economic and social development by pursuing a policy stance that ensures a sense of balance between taxation, expenditure and borrowing that is consistent with sustainable growth (Ocran 2009). Macroeconomic policies (fiscal and monetary) are indispensable tool that can be used to lessen short-run fluctuations in output and employment (Oke, 2013). They have been recognised in policy debates by both developed and developing economies as potent apparatus in the hands of policy makers for handling macroeconomic issues like high productivity, unemployment, inadequate national savings, excessive budget deficits, and large public debt burdens.

Productivity has been defined as the ratio between the output volume and the volume of inputs. It is the measure of how efficiently production inputs, such as labour and capital, are being used in an economy to produce a given level of output (Ariyo, 1993). Productivity is considered a key source of economic growth and competitiveness and, as such, is basic statistical information for country performance assessments. For example, productivity data are used to investigate the impact of product and labour market regulations on economic performance. Productivity growth constitutes an important element for modelling the productive capacity of economies. It also allows analysts to determine capacity utilisation, which in turn allows one to gauge the position of economies in the business cycle and to forecast economic growth. In addition, production capacity is used to assess demand and inflationary pressures (Ahmed, 2006).

The role of fiscal policy on the output and capacity utilization of the industry sector cannot be overemphasized. Fiscal policy drives the market for the manufacturing sector through the purposeful manipulation of government revenue and expenditure. When government is pursuing an expansionary policy, it reduces taxation and increases expenditure, thus increasing the purchasing power of the economic units which in turns expands the market for manufactured products. This sends a signal to the manufacturers to increase their productive capacity to take opportunity of the increase market demand. The reverse holds when a contractionary policy is being pursued. Fiscal policy also provides the legal, social and economic framework required for a profitable operation. In view of this role played by fiscal policy in the economy, this study is intended to investigate how fiscal policy impacts on selected macroeconomic variables such as savings and productivity in Nigeria.

\section{STATEMENT OF THE PROBLEM}

In spite of several fiscal measures established since independence and given the importance of fiscal policy in promoting the attainment of macroeconomic policy objectives, it seems that in Nigerian fiscal policy measure has not been able to live up to expectations. The abound arguments overtime that the capacity for fiscal policy to fully impact on the Nigerian economy and other macroeconomic variables has been seriously impaired by corruption, inappropriate and ineffective policies, lack of integration of macroeconomic plans, absence of harmonization and coordination of fiscal policy, gross Mismanagement/misappropriations of public funds and lack of economic potential for rapid economic growth and development.

There has been continuous adverse inflationary trend, undulating foreign exchange rates, fall and rise of gross domestic product unfavourable balance of payments, over reliance on oil revenue and high level of unemployment occasioned by low fiscal buffers, expansionary fiscal policy, high volume of maturing instruments; impact of external shocks, dwindling foreign exchange earnings; declining reserves; weak oil market and high unemployment. These culminated to the poor performance in macroeconomic variables.

Preponderance of studies on fiscal policy and other macroeconomic variables have continued to arrive at conflicting results making their relationship difficult to understand. There seem to be no well-established conclusion regarding the direction and extent of the effect of fiscal policy on macroeconomic variables. This is exemplified in the instability in macroeconomic variables in recent time to the extent that it becomes difficult to make economic decisions using their outcomes. Furthermore, the available studies seem to be tailored towards fiscal policy and economic growth, with no single study on the on fiscal policy and macroeconomic dynamics. There exists an unsettled gap that needs to be bridged in order to give policy makers the basis 
upon which to formulate and implement interest rate policies that will promote savings, productivity, inflation and investment in Nigeria. This is the focus of this study.

\section{OBJECTIVES OF THE STUDY}

The major objective of this study will be to examine the impact of the fiscal policy on selected macroeconomic variables in Nigeria. The specific objectives include:

(i) To assess the impact of fiscal policy tools on the interest rate in Nigeria;

(ii) To examine the extent to which fiscal policy tools affects the economic growth in Nigeria;

\section{RESEARCH HYPOTHESES}

The following null hypothesis will be formulated for this study

$\mathbf{H}_{01}$ : Fiscal policy tools do not have any significant effect on interest rate in Nigeria;

$\mathbf{H}_{02}$ : Fiscal policy tools do not have any significant effect on economic growth in Nigeria;

\section{LITERATURE REVIEW AND THEORETICAL FRAMEWORK \\ Theoretical framework}

Many theories of fiscal policy and macroeconomic variables exist but this study will only review Wagner's law of increasing scale of public expenditure, Keynesian fiscal theory of output and income, savers spender's theory and the classical theory. The study is however founded on the theoretical postulates of Mankiw (2000).

The Savers-Spenders Theory

Savers-Spenders theory of fiscal policy was developed by Mankiw (2000) and used by Matsen, Sveen and Torvik (2008). This theory was developed because of inconsistence of Barro-Ramsey (1974) theory of infinitely-lived families. Savers-Spenders theory is the new theory developed to explain the behavioural pattern of fiscal policy in the economy. The theory is based on some prepositions (Mankiw, 2000).

The first proposition is on temporary tax changes having large effects on the demand for goods and services. This proposition states that the higher take-home pay that spenders received will be offset by higher tax payments, or by lower tax refunds. The implication is that consumers should realize that their lifetime resources were unchanged and therefore, should save the extra take-home pay to meet the upward tax liability.
The second proposition is on government debt in relation to crowd out capital in the long-run. This proposition states that extra consumption reduces investment, which in turn raises marginal product of capital and as well decrease the level of economic growth. It is also of the opinion that higher interest rate margin, induces savers to save more. The implication of this proposition is that extra consumption and higher interest rate margin affect the growth of manufacturing sector which in turn reduce economic growth in Nigeria. The third proposition states that government debt increases steady-state inequality. This means that a higher level of debt means a higher level of taxation to pay interest on debt. The tax will fall on both the savers and the spenders but the interest will only fall on savers. The implication of this is that a higher level of debt rises the income and consumption of the savers and lowers the income and consumption of the spenders.

\section{KEYNESIAN FISCAL THEORY OF OUTPUT AND INCOME}

John Maynard Keynes (1883-1946) formulated a theory, which supports government serious participation in economic growth and development. Specifically, he postulated that in order to correct prolonged unemployment and depression in an economy, government has to intervene in the economy through taxation and government expenditures in order to promote output, growth and employment. He also pointed out that to solve the problems of unemployment in the economy, which is a situation where output is below full employment level, an appropriate fiscal policy measure must be taken. This type of policy could be either raising government expenditures or cutting taxes or combination of both. It needs be said that government of many countries accepts fiscal policy as an effective management instrument for government revenue mobilization and utilization. The policy consists of two components, changes in government expenditure and changes in taxation.

In Keynesian theory, spending is what stimulates output, and thus creates employment and generates income. This theory is based on the fact that aggregate demand, which is total spending, induces business firms to supply goods and services. If therefore total spending in an economy declines arising either from pessimism about future economic environment or from saving more of the current income, the business firms will respond by cutting down production (Nyong, 2001). Thus, less spending 
results in a fall in output. This of course leads to a decline in many other macroeconomic variables. The theory indicates that variation in government expenditure has a direct effect on income through the multiplier. Therefore, government expenditure is an important component of aggregate demand. Moreover, increase in government taxation, tax rate or lump sum tax has a negative impact on economic activity. Thus, whereas increase in government expenditure promotes economic activity, increase in taxation has opposite effect of decreasing economic activity, given that taxation is withdrawal from income stream while expenditure is an injection (Nyong, 2001). This therefore shows that the use of fiscal policy through changes in government expenditure promotes economic activity and hence growth at all levels.

Keynes submitted that the lingering unemployment and economic depression were a result of failure on the part of the government to control the economy through appropriate economic policies (Iyoha,2003). Consequently, Keynes proposed the concept of government intervention in the economy through the use of macroeconomic policies such as fiscal and monetary policies. Fiscal policy deals with government deliberate actions in spending money and levying taxes with a view to influencing macroeconomic variables in a desired direction. This includes sustainable economic growth, high employment creation and low inflation (Ekpo, 2010). Thus, fiscal policy aims at stabilizing the economy. Increases in government spending or a reduction in taxes tend to pull the economy out of a recession; while reduced spending or increased taxes slow down a boom (Dornbusch and Fischer, 1990).

Government interventions in economic activities are basically in the form of controls of selected areas/sectors of the economy. These controls differ, and depend on the specific needs or purpose the government desires to achieve. Keynes recommend government intervention through fiscal policy.

The Classical Theory

The earliest organised school of Macroeconomic thought is the classical school. Classical economics is a synthesis of theories put forth by numerous individuals from Adam Smith's time (the late 1700s) to the earliest twentieth century. The classical economists were proponents of the price mechanism (market system) which assumes a smooth functioning market where there is effective resource allocation and a guarantee to economic freedom to all and sundry with built- in flexibility that exclude the need for conscious government planning and intervention.

It however has certain limitations and inefficiencies resulting in a condition referred to as "market failure". The market failed to achieve a satisfactory level of welfare for the society by providing an equitable or fair distribution of income and wealth, or all of these. The 1930s great depression was a confirmation of the reality of the failure of the market economy which led to the evolution of Keynesian economics.

The fundamental principle of the classical theory is that the economy is self- regulating. Classical economists maintained that the economy is always capable of achieving the natural level of the real GDP that is obtained when the economy's resources are fully employed. While circumstances arise from time that cause the economy to fall below or to exceed the natural level of the real GDP, self-adjustment Mechanisms exist within the market system that work to bring the economy back to the natural level of real GDP. The classical doctrine, that the economy is always at or near the natural level of real GDP is based on two firmly held beliefs which are Say's law and the belief that prices, wages and interest rates are flexible.

According to says law when an economy produces a certain level of real GDP, it also generates the income needed to purchase that level of real GDP. In other words, the economy is always capable of demanding all of the output that its workers and firms chose to produce. Hence the economy is always capable of achieving the natural level of real GDP. However, the achievement of the natural level of real GDP is not as simple as Say's law would seem to suggest. While it is true that the income obtained from producing a certain level of real GDP must be sufficient to produce that level of real GDP, there is no guarantee that all of this income will be spent. Income that is saved is not used to purchase consumption goods and services implying that the demand for these goods and services will be less than the supply.

Wagner's law of increasing scale of public expenditure

This study reviewed Wagner's (1962) Law of increasing scale of public expenditure. According to Wagner, the public sector plays a significant role in the management of an economy at all level as of development. This role is usually through its revenue and expenditure policy (fiscal policy). The theory of public expenditure development posits that the role of public spending involves in the course of 
development since the budgetary function must adapt to the changing needs of the economy. The varying needs of the economy relates to both the allocation and distribution perspectives of public expenditure. The allocation perspective deals with the rising share of the public sector in the economy. That is there is a statistical direct relationship between the growth in public sector size and the growth and development of an economy.

The premise of the theory is that in growing economies, the increasing scale of public expenditure naturally increases income. In order to justify this generalisation into a theoretical fashion, Wagner divides public expenditure into two categories, namely security (including internal and external) and those of welfare. As the level of development increases, the level of expenditure cannot remain constant in many growing economies like Nigeria, the share of public sector in national income has been increasing (Ojong, Ogar and Arikpo, 2016). That is why the government's annual budget dictates the nature and direction of economic activities and the provision of social and economic services to meet the needs of the citizenry. But the question is that, has the increase in the level of public expenditure commensurate with the level and dimension of economic growth in Nigeria? Has this led to the reduction of poverty in the country? These questions are pertinent in view of the huge amounts of fund allocated for expenditures as reflected in the annual budgets in Nigeria.

\section{CONCEPTUAL FRAMEWORK}

Conceptual framework is a diagram that represent relationships between variables and shows the transmission path of the variables study. In this study the transmission mechanism of the fiscal policy (measured by government expenditure, government revenue and government debt) to macroeconomic variables such as interest rate and economic growth (GDP) as shown in the figure 1 below.

Macroeconomic variable

Fiscal policy

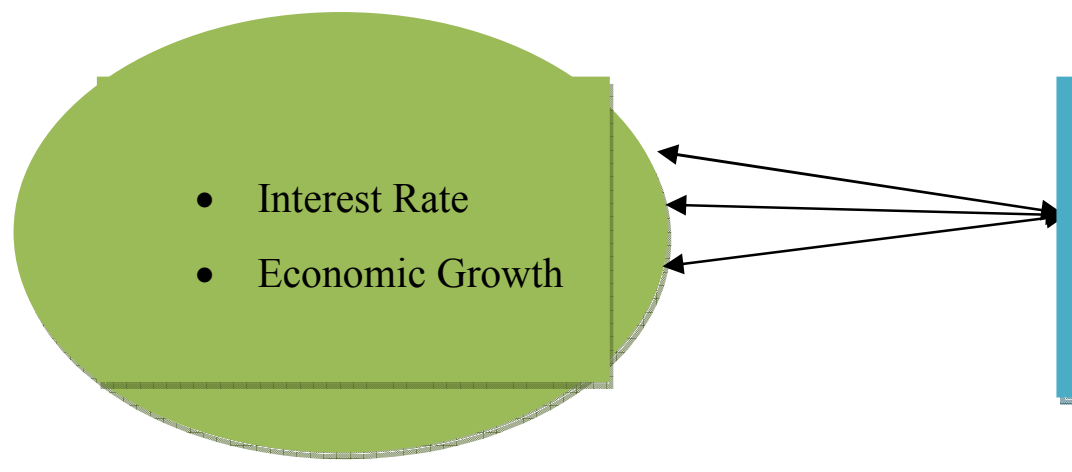

- Government Expenditure

- Government Revenue

- Government Debt

Figure 1: Conceptual framework

Source: Researcher's 2018

\section{REVIEW OF EMPIRICAL LITERATURE}

Countless studies have examined the relationship between fiscal policy, growth in developed, developing and emerging economies, interest rate and inflation. Abdurrauf (2015) examined fiscal policy and economic development in Nigeria. This study examined the short and long run impact of fiscal policy on economic development in Nigeria between a period of 1981 and 2013 using annual time series data soured from world development indicators (2014) and the central bank of Nigeria (2014). It used government recurrent expenditure, government capital expenditure, government investment and tax revenue to indicate fiscal policy. Economic development was proxied by real per capita income. The model was estimated using pair-wise correlation to ascertain the relationship and then cointegration and error correction mechanism for impact after confirming the data's stationarity using unit root. The result showed that government recurrent expenditure and government investment have significant positive impact on economic development in both the short and long run within the period under consideration. Capital expenditure appeared to have a short run positive impact but not in the long run. Tax revenue had an inverse significant impact in both short and long run. The speed of adjustment to equilibrium was found to be high. The results are all in line with theories and previous studies. 
Adenikinju and Olofin (2000) focus on the role of economic policy in the interest rate performance in African countries. They utilize panel data for seventeen African countries over the period 1976 to 1993. Their econometric evidence indicates that government policies aimed at encouraging foreign direct investment, enhancing the external competitiveness of the economy, and maintaining macroeconomic balance have significant effects on interest rate performance in Africa.

Phillips (1997) critically analyses the Nigerian fiscal policy between 1960 and 1997 with a view to suggesting workable ways for the effective implementation of Vision 2010. He observes that budget deficits have been an abiding feature in Nigeria for decades. He notes that except for the period 1971 to 1974 , and 1979, there has been an overall deficit in the federal Government budgets each year since 1960 to date. The chronic budget deficits and their financing largely by borrowing, he asserts, have resulted in excessive money supply, worsened inflationary pressures, and complicated macroeconomic instability, resulting in negative impact on external balance, investment, employment and growth. He, however, contends that fiscal policy will be an effective tool for moving Nigeria towards the desired state in 2010 only if it is substantially cured of the chronic budget deficit syndrome it has suffered for decades.

Peter and Simeon (2011) investigated the impact of fiscal policy variables on Nigeria's economic growth between 1970 and 2009. The study employed Vector error correction mechanism (VECM) techniques. The study revealed that there exists a long-run equilibrium relationship between economic growth and fiscal policy variables in Nigeria. Consequently, it was recommended that government should formulate and implement viable fiscal policy options that will stabilize the economy. This could be achieved through the practice of true fiscal federalism and the decentralization of the various levels of government in Nigeria.

Onuorah and Akujuobi (2012) examined the trend and empirical analysis of public expenditure and its impact on the economic growth in Nigeria. The study employed Johansen Co-integration and VECM and found that RGPE established long run relationship with RGDP. Finally, there is no statistical significance between public expenditure variables and the economic growth in Nigeria. The study recommended that government should embark on realistic policy implementation with sincere fiscal and monetary policies in place that can monitor to greater extend and help in the sustainability for remarkable growth to be recorded in the Nigeria. Ogbole, Sonmyand Isaac (2011) examined the impact of fiscal policy on economic growth in Nigeria during regulation and deregulation periods. Results obtained showed that there is a difference in the effectiveness of fiscal policy in stimulating economic growth during and after regulation periods. The impact was marginally higher (only N140 million or $14 \%$ contribution to GDP) during deregulation, than in the regulation period. The study recommended appropriate policy mix, prudent public spending, setting of achievable fiscal policy targets and diversification of the nation's economic base, among others.

Sikiru and Umaru (2012) investigated the impact of fiscal policy on economic growth in Nigeria. Annual data covering 1977 - 2009 were utilized. Unit roots of the series were examined using the Augmented Dickey-Fuller technique after which the cointegration test was conducted using the Engle-Granger Approach. Error-correction models were estimated to take care of short-run dynamics. The study found that productive expenditure positively impacted on economic growth during the period of coverage and a longrun relationship exists between them as confirmed by the cointegration test and recommended the improvement in government expenditure on health, education and economic services, as components of productive expenditure, to boost economic growth.

Bogunjoko (2004) examines the growth performance in Nigeria. He adopted a linear equation of the production function as suggested by Ram (1989). In order to complement the single equation model and account for the interdependency of expenditure and growth in Nigeria, a vector autoregressive model of three variables namely real output, federal government expenditure and state government expenditure was employed. Based on the Ram - type production function, the empirical results show that while the externality of the alternative expenditure (i.e. federal and state) is positive, the overall impact of the expenditure is growth retarding. This finding complements the argument that federal and state expenditures are made without due reference to the absorptive capacity of the economy. His VAR model shows that, inter - temporally, the response of real output to state and federal expenditures is weak in the short run. Aigbokhan (1996) opined that federal government spending if employed efficiently could boost private investment and promote economic growth. 
Vincent, Loraverand Wilson(2012) investigated the relationship between fiscal deficits and economic growth. Although macroeconomic theory postulates that fiscal deficits stimulate economic growth, empirical research has been less conclusive about this relationship and adopted a modeling technique that incorporates cointegration and structural analysis. The results indicated that fiscal deficit affects economic growth negatively and there is a strong negative association between government consumption expenditure and economic growth.

Ogbole, Sonny and Isaac (2011) focussed on the comparative analysis of the impact of fiscal policy on economic activities in Nigeria during regulation and deregulation, using the econometric methods of co-integration and error correction model. The study indicates that there is a difference in the effectiveness of fiscal policy in stimulating economic growth during and after regulation period. They recommend that government fiscal policy should refocus and redirect government expenditure towards production of goods and services so as to enhance GDP growth. This study fails to determine the contribution of fiscal policy on the economy during and after regulation.

Sikiruand Umaru (2011) studied the causal link between fiscal policy and economic growth in Nigeria, using Engle-Granger approach and error correction models which was estimated to take care of short-run dynamic. The result indicates that productive expenditure positively impacted on economic growth during the period covered. They also fail to confirm the other element in the link whereby fiscal policy should be more strongly associated with output and input measures in the economy.

Arikpo, Ogarand Ojong (2017) examined the impact of fiscal policy on the performance of the manufacturing sector in Nigeria using government revenue, expenditure and manufacturing output as the variables. The study adopted an ex-pose facto research design and data were collected for the period 1982 to 2014 . The data were analyzed using the ordinary least square multiple regression statistical technique. Result from the analyses revealed that increases in government revenue reduce manufacturing sector output in Nigeria. Also, increases in government expenditure enhance manufacturing output in Nigeria. the study recommended that Government should enhance its revenue base by diversifying its revenue sources as this will provide sufficient revenue to run government activities and enhance manufacturing performance in the long run. Also, manufacturing operators should always be encouraged through the granting of tax holidays and rebates, subsidizing of manufacturing inputs and the formulation of policies to promote manufacturing activities in Nigeria. Finally, Government should increase it expenditure on infrastructural development and community services as this will have a multiplier effect on manufacturing activities and enhance economic growth in Nigeria.

Ogar, Eyo and Arikpo (2019) examined the impact of government expenditure on the growth of the Nigerian economy using government capital, government recurrent expenditure, government fiscal deficit on the growth of the Nigerian economy. The ex-post facto design was adopted and secondary data were sourced from the CBN statistical bulletin and collected using desk survey for the period 1980 to 2017. The VAR technique was applied among other techniques to analyse the data. Findings showed that government capital expenditure had a positive but insignificant effect on the growth of the Nigerian economy. Also, it was revealed that government fiscal deficit had insignificant negative effect on the growth of the Nigerian economy. Lastly, the study revealed that at the short run, government recurrent expenditure had an insignificant positive effect on the growth of the Nigerian economy while in the long run it has a positive but insignificant effect on economic growth. Based on these findings, it was recommended that Government should revamp non-functioning capital projects to reduce the inefficiency in capital expenditure and monitor its contract awarding process closely, to prevent over estimation of execution cost and boost economic growth; government should enhance it recurrent expenditure to sustain the growth potentials of the economic through increasing it expenditure in running governmental activities and the planning and coordination of expenditure process of government should be made more efficient to avoid running into deficit and promote surplus funding of public expenditure.

\section{RESEARCH METHODOLOGY}

\section{RESEARCH DESIGN}

The study combined the exploratory design and the ex-post facto design to collect and analyze the data for this study. The exploratory design was used to access the relevant theories and literature as well as some empirical bases that provided the structure on which the study lied. 
The ex-post facto design on the other hand, was applied to collect the data on the study's variables, analyze and test them. This design is appropriate as the event under study had already taken place. The researcher had no control over the variables simply because they had already been manipulated before they were applied in this study.

\section{SOURCES OF DATA}

Time series data will be used for this study for the reasons that they give information about the numeric values of the variables. Annual time series data from 1980-2016 will be collected to determine the relationship between fiscal policy instruments and selected macroeconomic variables such as interest rate and GDP in Nigeria. The choice of these variables was largely informed by data availability. The endogenous variables include the output proxy by Gross Domestic Product (GDP)and interest rate while the exogenous variables will include government expenditure, government revenue and government debt. Data used in this study will be gotten from the Central Bank of Nigeria Statistical Bulletin, Volume, 27, (2016).

\section{MODEL SPECIFICATION}

The functional relationship between the variables of this stud could be expressed thus:

MACV $=f(F P)$

Where:

MACV = Macroeconomic Variables

FP = Fiscal Policy

This study however considers fiscal policy in terms of government expenditure, government revenue and government debt as exogenous variables against interest rate, inflation rate, economic growth as endogenous variables. This relationship is stated thus:

$$
\begin{aligned}
& \text { INR }=\mathrm{f}(\text { GEX, GRE GDT) } \\
& \text { INR }=b_{0}+b_{1} G E X+b_{2} G R E+b_{3} G D T+e \\
& \text { GDP = } f(G E X, G R E \text { GDT) . } \\
& \text { GDP }=a_{0}+a_{1} G E X+a_{2} \text { GRE }+a_{3} G D T+e \\
& \text { Where } \\
& \text { GDP }=\text { Gross Domestic Product (Output) } \\
& \text { INR = Interest Rate } \\
& \text { GEX }=\text { Government Expenditure } \\
& \text { GRE = Government Revenue } \\
& \text { GRE }=\text { Government Debt } \\
& a_{0} \text { and } b_{0}=\text { Regression constant } \\
& a_{1}-a_{3} \text { and } b_{1}-b_{3}=\text { Regression parameters }
\end{aligned}
$$

\section{ESTIMATION TECHNIQUES \\ DESCRIPTIVE STATISTICS}

The study will employ the descriptive statistics to examine the structure of the time series using descriptive analytical tools such as simple tables, graphs and percentages. Descriptive analysis will enable the study to appreciate the trend and pattern of the time series within the period of this study.

Unit root test

The study will employ the Augmented Dickey Fuller (ADF) and the Philip Perion unit root test to examine whether the time series is stationary since time series data usually follow a particular trend and since economic theory requires that they be subjected to differencing or de-trending procedures to avoid spurious results. Using the Augmented Dickey Fuller (ADF) and Philip Perion
(PP) tests for unit root test, we expect all the variables to be integrated at first difference and their coefficient to be negative. In other words, the time series data are expected to be integrated of order I (1) and I (0).

Vector error correction model (VECM)

This study will employ the Vector error correction mechanism (VECM) approach to estimate the relationship between the variables of this study. If there is evidence of cointegration in the model, then a valid error correction model also exists among the variables of model, meaning that we will proceed to run an error correction model. In other words, if all the series are integrated at order I (1) then we will proceed to estimate the relationship among the variables of the study using the VECM approach. Since we have two 
endogenous variables, the Vector Error Correction Model (VECM) will be estimated thus:

$\Delta \mathrm{INR}_{\mathrm{t}}=\sum_{\mathrm{I}=1}^{\mathrm{P}=1} \rho_{\mathrm{I}} \Delta \mathrm{InGRE}_{\mathrm{t}-1}+\sum_{\mathrm{I}=1}^{\mathrm{P}=1} \rho_{\mathrm{I}} \Delta \operatorname{InGEX}_{\mathrm{t}-1}+\sum_{\mathrm{I}=1}^{\mathrm{P}=1} \rho_{\mathrm{I}} \Delta \mathrm{InGDT}_{\mathrm{t}-1}+\mathrm{Z1}^{*} \mathrm{ECM}_{\mathrm{t}-1}+\mathrm{e}_{1 \mathrm{t}}$

$\Delta \mathrm{InGDP}_{\mathrm{t}}=\sum_{\mathrm{I}=1}^{\mathrm{P}=1} \varepsilon_{1} \Delta \mathrm{InGRE}_{\mathrm{t}-1}+\sum_{\mathrm{I}=1}^{\mathrm{P}=1} \varepsilon_{1} \Delta \mathrm{InGEX}_{\mathrm{t}-1}+\sum_{\mathrm{I}=1}^{\mathrm{P}=1} \varepsilon_{1} \Delta \mathrm{InGDT}_{\mathrm{t}-1}+\mathrm{Z3}^{*} \mathrm{ECM}_{\mathrm{t}-1}+\mathrm{e}_{3 \mathrm{t}}$

Where:

$\rho_{1}, \lambda_{1}, \varepsilon_{1}$ and $\alpha_{1}=$ Short Run Coefficient

ECM1, ECM2 and ECM3 = Error Correction Terms

$\mathrm{e}_{1 \mathrm{t},}$ ande $\mathrm{e}_{2 \mathrm{t}}=$ Residuals in equations (5) and (6)

$\mathrm{ECM1}_{\mathrm{t}-1}=$ Lagged Valued of the Residuals

Derived from the Cointegration Regression of

GRE, GEX and GDT on INR

$\mathrm{ECM}_{\mathrm{t}-1}=$ Lagged Valued of the Residuals Derived from the Cointegration Regression of GRE, GEX and GDT on GDP

Negative and significant $E C M 1_{t-1}$, and $E C M 2_{t}$ ${ }_{1}$ coefficient imply that there is long run causality from the independent variables, of GRE, GEX and GDT to the dependent variables INR and GDP. The short run causality from the independent variables to the dependent variables will also be tested using the Wald test statistics.

\section{VALIDATION TECHNIQUES}

To validate the stability of the estimates generated by the VECM technique, the CUSUM test will be applied. CUSUM (cumulative sum control chart) is a sequential analysis technique developed. The CUSUM charts plots the cumulative sums of the deviations of the sample values from a target value. Furthermore, the study will apply the Breusch-Godfrey serial correlation LM test, the normality test and the heteroskedasticity test to check whether or not the residuals of the model are interdependent. Lastly, the study will apply the Wald test to assess whether or not the independent lagged variables have jointly effect on the dependent variable.

\section{ANALYSIS OF DATA DESCRIPTIVE STATISTICS}

Table 1: Descriptive Statistics

\begin{tabular}{llllll}
\hline & INR & \multicolumn{1}{l}{ LGDP } & \multicolumn{1}{l}{ LGEX } & \multicolumn{1}{l}{ LGRE } & \multicolumn{1}{l}{ LGDT } \\
\hline Mean & 12.70919 & 8.424874 & 5.798217 & 4.850497 & 6.845459 \\
Median & 12.75000 & 8.576850 & 6.188490 & 5.111988 & 7.085567 \\
Maximum & 26.00000 & 11.52771 & 8.644536 & 8.548835 & 9.310928 \\
Minimum & 6.000000 & 4.975561 & 2.265921 & 1.057790 & 2.311545 \\
Std. Dev. & 4.182229 & 2.277125 & 2.245547 & 2.501799 & 2.069318 \\
Skewness & 0.718539 & -0.185614 & -0.294874 & -0.192118 & -0.761493 \\
Kurtosis & 4.177149 & 1.588453 & 1.613338 & 1.586461 & 2.379047 \\
Jarque-Bera & 5.320096 & 3.284172 & 3.500559 & 3.308000 & 4.170317 \\
Probability & 0.069945 & 0.193576 & 0.173725 & 0.191283 & 0.124287 \\
Sum & 470.2400 & 311.7204 & 214.5340 & 179.4684 & 253.2820 \\
Sum Sq. Dev. & 629.6773 & 186.6708 & 181.5293 & 225.3239 & 154.1548 \\
Observations & 37 & 37 & 37 & 37 & 37 \\
\hline
\end{tabular}

Source: Researchers' Eview 9.1 Computation, 2018

We begin this section by comprehensively examining the descriptive statistics of the data set. Table1 shows the result of the descriptive statistics of the effect of fiscal policy on macroeconomic factors in Nigeria. From the result, it could be observed that the mean values of INR, GDP, GEX, GRE and GDT are respectively12.70919, 8.424874, 5.798217, 4.850497 and 6.845459 with their standard deviations of $4.182229,2.277125,2.245547$, 2.501799 and 2.069318 ranging respectively from 6.000000 to $26.00000,4.975561$ to $11.52771,2.265921$ to $8.644536,1.057790$ to 8.548835 and 2.311545 to 9.310928 .

It is worthy of note that the measurement of skewness indicates not only the amount of skewness but also the direction of the data distribution. A close examination of the skewness of the data set as shown in table 1 revealed that all the variables except INR were negatively skewed (left skewed distribution), meaning that their means are also to the left of the peak. 
Kurtosis measures the peakedness or flatness of the data relative to the normal distribution. The coefficient of the kurtosis of the variables indicates that GDP, GEX, GRE, and GDT were platykurtic below 3.000000 relative to the normal, meaning that the distribution produces fewer and less extreme outliers than does the normal distribution. INR is leptokurtic relative to the normal meaning that the distribute on produces more outliers than the normal distribution.
The Jarque-Bera (JB) test measures the difference of the skewness and kurtosis of the series with those from the normal distribution. The JB values of 5.320096, 3.284172, 3.500559, 3.308000 and 4.170317 for INR, GDP, GEX, GRE and GDT respectively with their respective p-values of 6.99 percent, 19.36 percent, 17.37 percent, 19.13 percent and 12.43 percent are greater than 5 percent showed that the data set are normally distributed.

Unit root test

Table 2: Augmented Dickey Fuller (ADF) Unit Root Test

\begin{tabular}{llll}
\hline \multirow{2}{*}{ Variables } & \multicolumn{2}{l}{ ADF Test Statistics } & Order of integration \\
\cline { 2 - 3 } & \multicolumn{1}{l}{ Level } & $1^{\text {st }}$ Difference & \\
\hline INR & -2.863666 & -7.607610 & $\mathrm{I}(1)$ \\
LGDP & -1.397139 & -38.27952 & $\mathrm{I}(1)$ \\
LGRE & -0.322916 & -7.929826 & $\mathrm{I}(1)$ \\
LGEX & -0.556371 & -7.023427 & $1(1)$ \\
LGDT & -2.641654 & -4.049500 & $\mathrm{I}(1)$ \\
\hline
\end{tabular}

Test critical values at level: $1 \%=-3.626784,5 \%=-2.945842,10 \%=-2.611531$

Test critical values at $1^{\text {st }}$ Diff: $1 \%=-3.632900,5 \%=-2.948404,10 \%=-2.612874$

Source: Researchers' Eview 9.1 Computation, 2018.

Table 2 showed that all the variables have unit root at levels but after differencing one time they all became stationary. This is so as the test statistics at levels, taking their absolute values were less than their critical values at 5 percent. However, after differencing one time, the test statistics, taking their absolute values became greater than their critical values at 5 percent level. Since the variables are integrated of the same order, we have to run a cointegration test using the Johansen co-integration test.
VAR lag order selection criteria

In order to select the appropriate lag order for this study, the optimal lag order selection criteria were applied. The result is as presented in table 3 . The basis for selecting the optimal lag for this study is the lag order selected by most of the VAR order criteria. From table 3 all criteria except the Akaike Information Criterion (AIC) selected lag one. Hence, for this study lag one is the most suitable lag order. 
Table 3: VAR lag order selection criteria

Endogenous variables: INR LGDP LGEX LGRE LGDT

\begin{tabular}{lllllll}
\hline \hline Lag & LogL & LR & FPE & AIC & SC & HQ \\
\hline \hline 0 & -171.0521 & NA & 0.021638 & 10.35600 & 10.58047 & 10.43255 \\
1 & -8.949943 & $266.9917^{*}$ & $6.93 \mathrm{e}-06^{*}$ & 2.291173 & $3.637962^{*}$ & $2.750467^{*}$ \\
2 & 17.29326 & 35.50551 & $7.13 \mathrm{e}-06$ & 2.218043 & 4.687156 & 3.060081 \\
3 & 43.28325 & 27.51881 & $8.92 \mathrm{e}-06$ & $2.159809^{*}$ & 5.751245 & 3.384591 \\
\hline \hline
\end{tabular}

* indicates lag order selected by the criterion

LR: sequential modified LR test statistic (each test at $5 \%$ level)

FPE: Final prediction error

AIC: Akaike information criterion

SC: Schwarz information criterion

$H Q$ : Hannan-Quinn information criterion

Source: Researchers' Eview 9.1 Computation, 2018.

Johansen cointegration

Table 4a: Unrestricted Co-Integration Rank Test (Trace)

\begin{tabular}{lllll}
\hline \hline $\begin{array}{l}\text { Hypothesized } \\
\text { No. of CE(s) }\end{array}$ & Eigenvalue & $\begin{array}{l}\text { Trace } \\
\text { Statistic }\end{array}$ & $\begin{array}{l}\text { 0.05 } \\
\text { Critical Value }\end{array}$ & Prob. ${ }^{* *}$ \\
\hline \hline None * & 0.896457 & 119.6810 & 69.81889 & 0.0000 \\
At most 1 & 0.498591 & 44.84452 & 47.85613 & 0.0933 \\
At most 2 & 0.331479 & 22.06354 & 29.79707 & 0.2950 \\
At most 3 & 0.191911 & 8.774866 & 15.49471 & 0.3866 \\
At most 4 & 0.051451 & 1.743124 & 3.841466 & 0.1867 \\
\hline \hline
\end{tabular}

Trace test indicates 1 cointegrating eqn (s) at the 0.05 level

* denotes rejection of the hypothesis at the 0.05 level

${ }^{* *}$ MacKinnon-Haug-Michelis (1999) p-values

Source: Researchers' Eview 9.1 Computation, 2018. 
Table 4b: Unrestricted Co-Integration Rank Test (Maximum Eigenvalue)

\begin{tabular}{lllll}
\hline \hline $\begin{array}{l}\text { Hypothesized } \\
\text { No. of CE(s) }\end{array}$ & Eigenvalue & $\begin{array}{l}\text { Max-Eigen } \\
\text { Statistic }\end{array}$ & $\begin{array}{l}0.05 \\
\text { Critical Value }\end{array}$ & Prob. $^{* *}$ \\
\hline \hline None & 0.896457 & 74.83651 & 33.87687 & 0.0000 \\
At most 1 & 0.498591 & 22.78098 & 27.58434 & 0.1830 \\
At most 2 & 0.331479 & 13.28867 & 21.13162 & 0.4260 \\
At most 3 & 0.191911 & 7.031742 & 14.26460 & 0.4854 \\
At most 4 & 0.051451 & 1.743124 & 3.841466 & 0.1867 \\
\hline \hline
\end{tabular}

Max-eigenvalue test indicates 1 cointegrating eqn(s) at the 0.05 level

* denotes rejection of the hypothesis at the 0.05 level

**MacKinnon-Haug-Michelis (1999) p-values

Source: Researchers' Eview 9.1 Computation, 2017.

The co-integration test results as presented in table $4 \mathrm{a}$ and $4 \mathrm{~b}$ indicate that there is one cointegrating equation in the model. The values of the test statistics in the co-integration equation for both trace test and maximum eigenvalues is found to be greater than their critical values at 5 percent significance level. Also, the p-values of the co-integrating equations are less than 5 percent meaning that the variables share a common stochastic trend and will grow proportionally. In other words, the move together in the long run meaning that they have long run association.

Table 5: Long Run and Short Run Dynamic Analysis of Equation One Dependent Variable: $\mathrm{D}(\mathrm{INR})$

\begin{tabular}{lllll}
\hline \hline & Coefficient & Std. Error & t-Statistic & Prob. \\
\hline \hline \multicolumn{1}{c}{ C(1) } & -0.006609 & 0.005569 & -1.186791 & 0.2453 \\
INR- C(2) & -0.212611 & 0.230933 & -0.920661 & 0.3651 \\
GDP- C(3) & 0.535744 & 0.712320 & 0.752111 & 0.4583 \\
GEX- (4) & -3.813903 & 4.304440 & -0.886039 & 0.3831 \\
GRE- C(5) & 0.947332 & 2.226756 & 0.425431 & 0.6738 \\
GDT- C(6) & 2.486320 & 2.318694 & 1.072293 & 0.2927 \\
$\quad$ C(7) & 0.196814 & 0.897980 & 0.219175 & 0.8281 \\
\hline \hline R-squared & 0.602576 & & & \\
Adjusted R-squared & 0.558861 & & & \\
F-statistic & 3.291100 & Durbin-Watson stat & 2.236436 \\
Prob (F-statistic) & 0.023411 & & & \\
\hline \hline
\end{tabular}

Source: Researchers' Eview 9.1 Computation, 2018. 
The result of the VECM estimation is presented in tables 5 and 8 respectively. From table $5, C$ (1) is the error correction term which measure the speed of adjustment of INR toward long run equilibrium. The expectation about $C(1)$ is that it must be negative and significant at 5 percent level. From the result above, $C(1)$ is negative but insignificant at 5 percent level. This means therefore that there is no long run causality from GEX, GRE and GDT to INR; meaning that fiscal policy has no influence on interest rate in the long run. In other words, there is no long run causality running from fiscal policy instruments to INR in Nigeria.

A review of table 5 above also shows that there is an inverse relationship between government expenditure and interest rate; a one percent increase in government expenditure, led to a 3.81 percent decrease in interest rate. In other words, as government expenditure increases, interest rate decrease and vice versa. Also, table 6 shows that government revenue has a positive effect on interest rate. This could be seen from the positive coefficient of the variable, meaning that a one percent increase in government revenue, led to a 94.7 percent increase in interest rate. In other words, as government revenue increases, interest rate decrease and vice versa. Lastly, table 5 shows that government debt has a positive effect on interest rate. This could be seen from the positive coefficient of the variable, meaning that a one percent increase in government debt, led to a 2.49 percent increase in interest rate. In other words, as government debt increases, interest rate increases accordingly.

Furthermore, the $\mathrm{R}^{2}$ value 0.602576 or 60.25 percent showed that about 60.25 percent of the observed behaviour in interest rate has been explained by the variations in fiscal policy tools such as government expenditure, government revenue and government debt. The F-statistics value of 3.2911 with it corresponding probability of 2.34 percent shows that the interest rate equation model is statistically robust at 5 percent level.

Table 6: Breusch-Godfrey Serial Correlation Lm Test For Fiscal Policy and Interest Rate Equation

\begin{tabular}{llll}
\hline \hline F-statistic & 3.612060 & Prob. F(2,26) & 0.0413 \\
Obs*R-squared & 7.610260 & Prob. Chi-Square(2) & 0.0223 \\
\hline \hline
\end{tabular}

Source: Researchers' Eview 9.1 Computation, 2018.

Checking the observed $R^{2}$ value of 7.610260 with

it corresponding prob. Chi-square (2) of 2.23 percent, we conclude that the model is suffering from serial correlation.

Table 7: Heteroskedasticity Test: Brueusch-Pagan-Godfrey For Fiscal Policy and Interest Rate Equation

\begin{tabular}{llll}
\hline \hline F-statistic & 0.974409 & Prob. F(10,24) & 0.4897 \\
Obs*R-squared & 10.10675 & Prob. Chi-Square(10) & 0.4312 \\
Scaled explained SS & 11.25450 & Prob. Chi-Square(10) & 0.3380 \\
\hline \hline
\end{tabular}

Source: Researchers' Eview 9.1 Computation, 2018. 
From the table the observed $R^{2}$ value of 10.1068 with it corresponding prob. Chi-square value of 43.12 percent which is more than five percent,

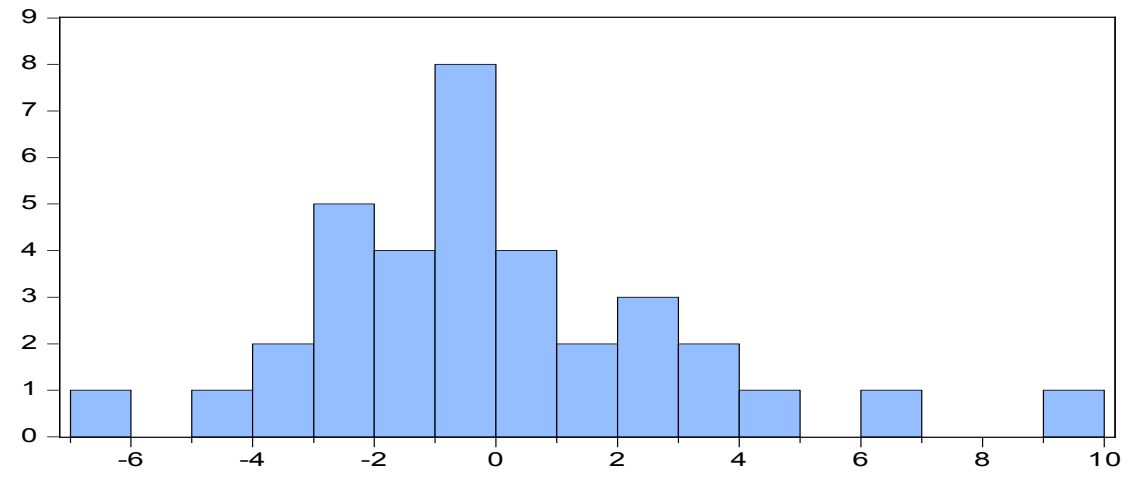

Source: Researchers' Eview 9.1 Computation, 2018. implies that the model is free from heteroskedasticity.
Series: Residuals Sample 19822016 Observations 35

Mean

Median $\quad-0.348966$

Maximum $\quad 9.697216$

Minimum $\quad-6.671724$

Std. Dev. $\quad 3.116718$

Skewness $\quad 0.786241$

Kurtosis $\quad 4.479882$

Jarque-Bera $\quad 6.799845$

Probability 0.033376
Figure 1: Histogram Normality Test For Fiscal Policy And Interest Rate Equation

The Jarque Bera statistics of 6.799845 with it corresponding probability of 3.33 percent, less than 5 percent, means that the residual of the fiscal policy and interest rate equations is not normally distributed.

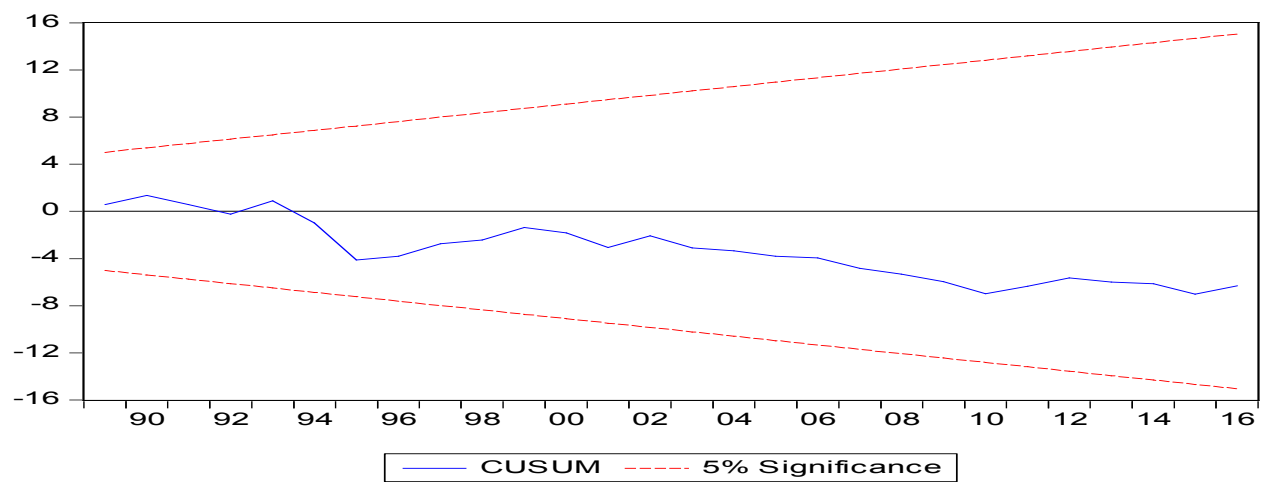

Source: Researchers' Eview 9.1 Computation, 2018.

Figure 2: Stability Test For Fiscal Policy And Interest Rate Equation

From the CUSUM Test result, it could be seen that the blue line lies in between the two red lines. This means that the estimates of our fiscal policy and interest rate relationship are stable and reliable. 
Table 8: Long Run And Short Run Dynamic Analysis of Equation Two

Dependent Variable: D(LGDP)

\begin{tabular}{lllll}
\hline \hline & Coefficient & Std. Error & t-Statistic & Prob. \\
\hline \hline C(8) & -0.000500 & 0.000119 & -4.203365 & 0.0002 \\
GDP- C(9) & -0.012755 & 0.004929 & -2.587720 & 0.0151 \\
INR- C(10) & -0.014014 & 0.015204 & -0.921738 & 0.3645 \\
GEX- C(11) & 0.101465 & 0.091873 & 1.104403 & 0.2788 \\
GRE- C(12) & 0.097959 & 0.047527 & 2.061100 & 0.0487 \\
GDT- C(13) & 0.004119 & 0.049490 & 0.083227 & 0.9343 \\
C(14) & 0.152097 & 0.019166 & 7.935630 & 0.0000 \\
\hline \hline R-squared & 0.624802 & & & \\
Adjusted R-squared & 0.544402 & & & \\
F-statistic & 7.771211 & Durbin-Watson stat & 1.575319 \\
Prob(F-statistic) & 0.000056 & & & \\
\hline \hline
\end{tabular}

Source: Researchers' Eview 9.1 Computation, 2018.

From table $8, C(8)$ is the error correction term which measure the speed of adjustment of GDP toward long run equilibrium. The expectation about $C(8)$ is that it must be negative and significant at 5 percent level. From the result above, $C(8)$ is negative and significant at 5 percent level. This means therefore that there is a long run causality from GEX, GRE and GDT to GDP; meaning that fiscal policy has an influence on GDP in the long run. In other words, there is a long run causality running from fiscal policy to the Nigerian economy.

A review of table 8 above also shows that there is a positive relationship between government expenditure, government revenue and government debt and the Nigerian economy. In other words, fiscal policy has a positive effect on economic growth in Nigeria in the short run, with only government revenue exerting significant influence in the short run. Furthermore, the $R^{2}$ value 0.6248 or 62.48 percent showed that about 62.48 percent of the observed behaviour in GDP has been explained by the variations in fiscal policy tools such as government expenditure, government revenue and government debt. The F-statistics value of 7.7712 with it corresponding probability of value less than 5 percent shows that the GDP equation model is statistically robust at 5 percent level.

Table 9: Breusch-Godfrey Serial Correlation LM Test for Fiscal Policy and GDP Equation

\begin{tabular}{llll}
\hline \hline F-statistic & 0.929073 & Prob. F(2,26) & 0.4076 \\
Obs*R-squared & 2.334510 & Prob. Chi-Square(2) & 0.3112 \\
\hline \hline
\end{tabular}

Source: Researchers' Eview 9.1 Computation, 2018.

From table 10 , the observed $R^{2}$ value is 2.3345 and it corresponding prob. Chi-square (2) is 31.12 percent, which is greater than 5 percent, hence, we conclude that the fiscal policy instruments and GDP equation has no serial correlation. 
OGAR, A., ARIKPO, O. F. AND SULEIMAN, L. G.

Table 10: Heteroskedasticity Test: Brueusch-Pagan-GodfreyforFiscal Policy, GDP Equation

\begin{tabular}{llll}
\hline \hline F-statistic & 2.706570 & Prob. F(10,24) & 0.0222 \\
Obs*R-squared & 18.55060 & Prob. Chi-Square(10) & 0.0464 \\
Scaled explained SS & 20.42753 & Prob. Chi-Square(10) & 0.0255 \\
\hline \hline
\end{tabular}

Source: Researchers' Eview 9.1 Computation, 2018.

From the table, the observed $R^{2}$ value of 18.551 with it corresponding prob. Chi-square value of
4.46 percent, less than five percent, implies that the model is not free from heteroskedasticity.
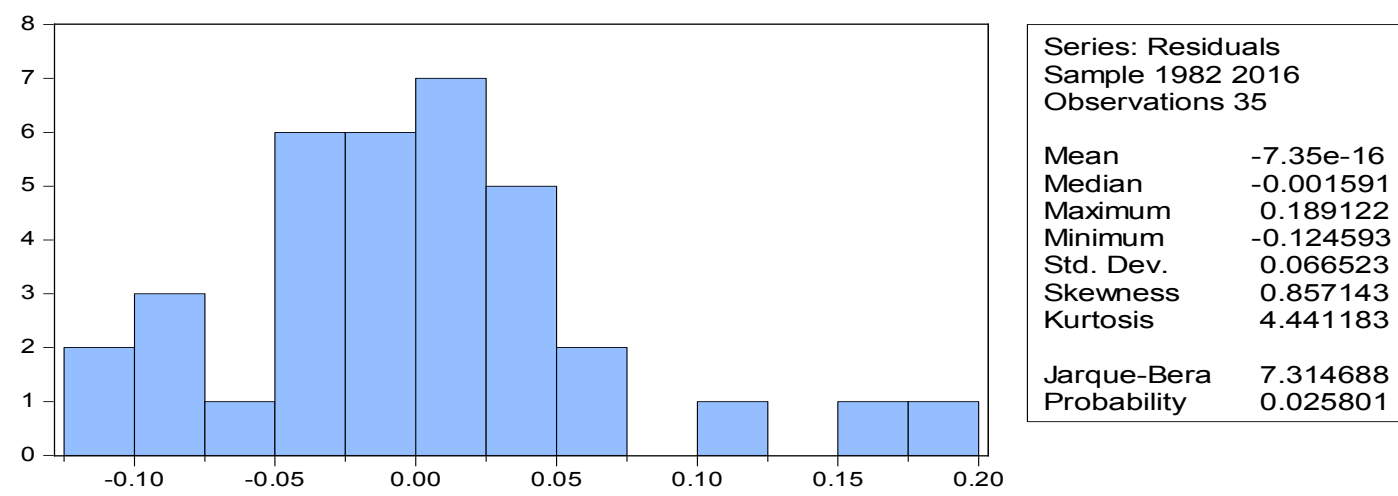

Source: Researchers' Eview 9.1 Computation, 2018.

Figure 3: Histogram Normality Test for Fiscal Policy, GDP Equation

The Jarque Bera statistics of 7.315 with it corresponding probability of 2.58 percent, less than 5 percent, implies that the residual of the fiscal policy, GDP equations is not normally distributed.

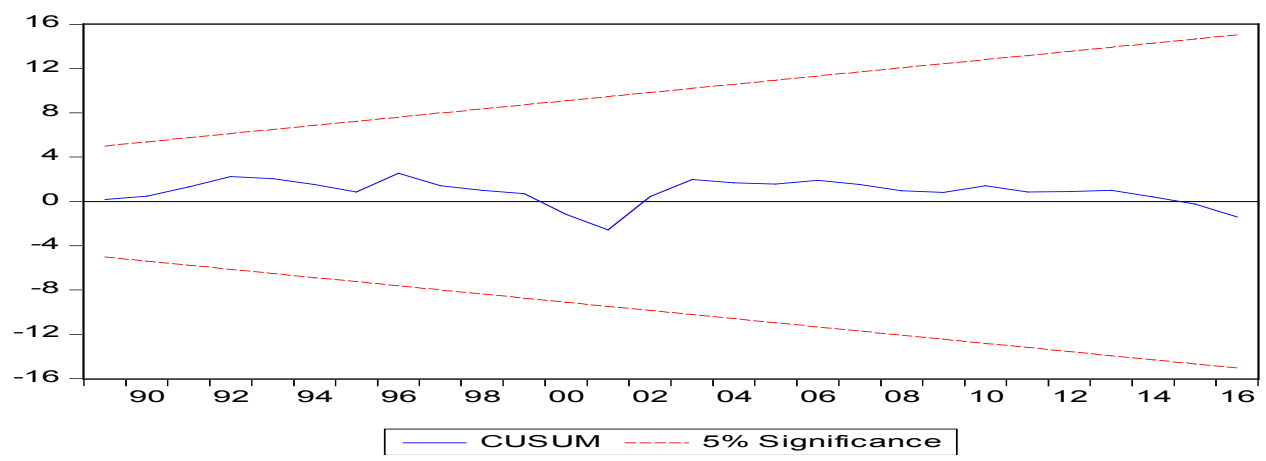

Source: Researchers' Eview 9.1 Computation, 2018. 
Figure 4: Histogram Normality Test for Fiscal Policy, GDP Equation

From the CUSUM Test result, it could be seen that the blue line lies in between the two red lines. This means that the estimates of our fiscal policy and GDP relationship are stable and reliable.

\section{TEST OF HYPOTHESES HYPOTHESIS ONE}

$\mathbf{H}_{01}$ : Fiscal policy tools do not have any significant effect on interest rate in Nigeria;

$\mathbf{H}_{1}$ : $\quad$ Fiscal policy have a significant effect on interest rate in Nigeria

\section{DECISION RULE}

Accept $\mathrm{H}_{0}$ : if calculated F-statistics value < table F-statistics value.'

Reject $\mathrm{H}_{0}$ : if calculated F-statistics value $>$ table F-statistics value.

From the regression result,

Calculated F-statistics value $=3.29$

Table F-statistics value $=2.52$

Since the calculated F-statistics value of 3.29 is greater than the table F-statistics value of 2.52 at 5 percent level of significance, we reject the null hypothesis and accept the alternative hypothesis. It therefore implies that fiscal policy has a significant effect on interest rate in Nigeria.

\section{HYPOTHESIS TWO}

$\mathrm{H}_{02}$ : Fiscal policy tools do not have any significant effect on economic growth in Nigeria;

$\mathrm{H}_{1}$ : $\quad$ Fiscal policy tools have a significant effect on economic growth in Nigeria

\section{DECISION RULE}

Accept $\mathrm{H}_{0}$ : if calculated F-statistics value < table F-statistics value.'

Reject $\mathrm{H}_{0}$ : if calculated $\mathrm{F}$-statistics value $>$ table F-statistics value.

From the regression result,

Calculated F-statistics value $=7.77$

Table F-statistics value $=2.52$

Since the calculated F-statistics value of 7.77 is greater than the table F-statistics value of 2.52 at 5 percent level of significance, we reject the null hypothesis and accept the alternative hypothesis. It therefore implies that fiscal policy has a significant effect on economic growth in Nigeria.

\section{DISCUSSION OF FINDINGS:}

This study focusses on government expenditure, government revenue and government debt on interest rate and GDP using the VECM analytical approach. The findings of this study have both long run and short run implications as discussed here. In the long run, government expenditure, government revenue and government debt had no significant effect on interest rate. This implies that there is no long run association between fiscal policy and interest rate. In other words, fiscal policy tools jointly do not influence the movement of interest rate in the long run. This finding agrees with Vincent, Loraver and Wilson(2012) who studied the relationship between fiscal policy and macroeconomic variables and found that interest rate and fiscal policy had no relationship in the long run.

In the short run, it was revealed that Government revenue and government debt have positive but insignificant effect on interest rate in Nigeria. Government expenditure on the other hand have an inverse and insignificant effect on interest rate in Nigeria.

The study also revealed that fiscal policy tools had a positive and significant effect on economic growth in the long run. However, in the short run, fiscalpolicy instruments have positive effect on economic growth with government expenditure and government debt exerting an insignificant influence on the economy in the short run. This implies that the more expenditure on infrastructure and other community development activities by government, the more the growth of the Nigerian economy in the long run. By this finding, an increase in fiscal policy results in a positive and proportional increase in the growth of the Nigerian economy. In the short run, increases in government expenditure and debt will result in positive but less proportional gains in the Nigerian economy. However, increases in government revenue in the short run will trigger positive and significant growth in GDP. This finding is in consonance with the finding of Asaju, Adagba and Kajang (2014) who examined the link between fiscal policy and economic growth and concluded that government fiscal policy tools are vibrant for growth. 
SUMMARY OF FINDINGS, CONCLUSION AND RECOMMENDATION

\section{Summary of Findings.}

This study examined fiscal policy tools effect on macroeconomic dynamics in Nigeria using the restricted VAR approach. Analyses shows that fiscal policy tools had impacted significantly on economic growth in Nigeria over the period of this study. However, fiscal policy tools have not really influenced the interest rate system in Nigeria both in the short run and long run. Drawing from the above, the study concludes that fiscal policy is an active policy for promoting economic growth in Nigeria.

\section{RECOMMENDATION.}

Based on the findings of this study, the following recommendations were made;

(i) Fiscal policy should be tailored towards sustaining economic growth and development; in view of this government avoid further borrowings as this may increase the debt servicing burden and result in a negativity effect on growth in the long run.

(ii) Fiscal policy should be used to complement monetary policy effects as if used alone may not achieve the desired target for interest rate in Nigeria.

\section{REFERENCES}

Adenikinju, A. and Olofin, S.O. 2000. Economic policy and manufacturing sector growth performance in Africa. The Nigeria Journal of Economic and Social Studies, 42(1), 1-14.

Ahmed, S. 2006. Does money affect output? Business Review Federal Reserve Back of Philadelphia, 13-28.

Akpapan, E. B. 1994. How to save the naira in Nigeria, macroeconomics action. Belpot Nig. Co. Abak.

Anyanwu J. C and Ohahenam H. E 1995. Modern macroeconomics: Theory and application in Nigeria. Joanee Educational Publisher Ltd.

Ariyo, A. 1993. An assessment of the sustainability of Nigeria's fiscal deficit, 1970-1990. Journal of African economics, 2(2), 263-282.
Arikpo, O. F., Ogar, A. And Ojong, C. M. 2017. The impact of fiscal policy on the performance of manufacturing sector in Nigeria. Euro-Asian Journal of Economics and Finance, 5 (1), 11-22. DOI: $10.9790 / 5933-07113238$.

Asaju, K., Adagba, S. O. And Kajang, T. J. 2014. The efficacy of fiscal policy in promoting economic growth and reducing poverty in Nigeria. Journal of Research in World Economy, 5(1),65-22

Dombusch, R. and Fischer, S. 1990. Macroeconomics $5^{\text {th }}$ ed.. New York: Mcgraw-Hill.

Ekpo, H. A. 2010. Nigeria and its budgeting expenditures dilemma. Business Journal. Retrieved from www. bsjournal.com

Mankiw, N. G. 2000. The savers-spenders theory of fiscal policy. Paper prepared for the meeting of the American Economic Association

Meig, W. and Meig, F. 2004. Accounting the basic business decision. USA: McGrawHill Book Company, 51-68.

Nyong, M. 2001. Deficits, government spending, and inflation: what is the evidence? Journal of Monetary Economics, 5(2), 6269.

Ocran, M. K. 2009. Fiscal policy and economic growth in south African. A paper presented at the centre for study of African economics, "conference on economic development in African" St. Catheviores College, Oxford University, UK, March 22-24, 2009.

Ogar, A., Eyo, I. E. And Arikpo, O. F. 2019. Public expenditure and economic growth in Nigeria: VAR approach. European Journal of Economics and Financial Research,3 (3), 11-22. DOI: 10.5281.zenodo. 2580458

Ogbole, F. O., Sonmy, N. A. and Isaac, D. E 2011. Fiscal policy: its impact on economic growth in Nigeria. Journal of Economics and International Finance, 3(6), 407-417. 
Ojong, M. O., Ogar, A. and Arikpo, O. F. 2016. The impact of tax revenue on economic growth: Evidence from Nigeria. ISOR Journal of Economics and Finance, 7 (1), 32-38. DOI: 10.9790/5933-07113238.

Oke, M. O. 2013. Budget implementation and economic growth in Nigeria. Developing Country Studies, 3 (13), 1-7

Okpanachi, U. M. 2004. Government deficit and the inflationary process in Nigeria, 19861998 unpublished Ph.D thesis Economics Department, University of Jos.

Onuorah, A. C. and Akujobi, L. E. 2012. Empirical analysis of public expenditure and economic growth in nigeria. Arabian Journal of Business and Management Review, 1(11), 46-57.

Peter, N. M. and Simeon, G. N. 2011. Econometric analysis of the impact of fiscal policy variable on Nigeria's economic growth 1970-2009. International Journal of Economic Development Research and Investment, 2(1), 171-183.
Philips, A. O. 1997 Nigeria fiscal policy, 19982010. Nigeria Institute of Social Economic Research (NISER), Monograph series No.17, Ibadan.

Ram, A. 1989. Causality between income and public expenditure: A broad international perspective. Public Finance/Finances Publishers, 31(3), 393-413.

Sikiru, J. B and Umaru, A. 2013. Fiscal policy and economic growth relationship in Nigeria. International Journal of Business and Social Science, 2(6), 85-96.

Sikiru, J. B. and Umaru, A. 2011. Fiscal policy and economic growth relationship in Nigeria. International Journal of Business Social sciences, 2(17), 244-249.

Vincent N. N., Loraver, N. and Wilson, E.H. 2012. Economic growth Evidence from Nigeria. Economics and Finance Review, 2(6), 85-96.

Wagner, A.1962. Three extracts on public finance, in Musgrave R. A. and Peacock, A. T. (eds), Classics in the theory of public finance. London: Macmillan. 